\title{
BACE1 Inhibitor, Neuroprotective, and Neuritogenic Activities of Melatonin Derivatives
}

\author{
Panyada Panyatip ${ }^{1,2}\left(\mathbb{D}\right.$, Sarin Tadtong ${ }^{3}$, Emília Sousa 4 (D) and Ploenthip Puthongking ${ }^{2,5, *(1)}$ \\ 1 Graduate School, Khon Kaen University, Khon Kaen 40002, Thailand; ppanyada90@gmail.com \\ 2 Melatonin Research Group, Faculty of Pharmaceutical Sciences, Khon Kaen University, \\ Khon Kaen 40002, Thailand \\ 3 Faculty of Pharmacy, Srinakharinwirot University, Nakhon-Nayok 26120, Thailand; sarin@swu.ac.th \\ 4 CIIMAR, Laboratório de Química Orgânica e Farmacêutica, Departamento de Ciências Químicas, \\ Faculdade de Farmácia, Universidade do Porto, 4050-313 Porto, Portugal; esousa@ff.up.pt \\ 5 Department of Pharmaceutical Chemistry, Faculty of Pharmaceutical Sciences, Khon Kaen University, \\ Khon Kaen 40002, Thailand \\ * Correspondence: pploenthip@kku.ac.th; Tel.: +66-43-203149
}

Received: 5 November 2020; Accepted: 2 December 2020; Published: 4 December 2020

\begin{abstract}
Alzheimer's disease (AD) is a common chronic neurodegenerative disorders. Melatonin (MLT) has been reported to be neuroprotective agent, and its modified structures exhibit potent antioxidant and anti-inflammation activities. Therefore, the activity of MLT and its derivatives against AD was investigated. Herein, the targeted enzymes, such as $\beta$-secretase (BACE1) and acetylcholinesterase (AChE), as well as the neuroprotective and neuritogenic effects on P19-derived neurons were evaluated. All the derivatives (1-5), including MLT, displayed potent inhibitory activity for BACE1, with inhibition values of more than $75 \%$ at $5 \mu \mathrm{M}$. A molecular docking study predicted that MLT, 5-MT, and 5 bound with BACE1 at catalytic amino acids Asp32 and the flap region, whereas 1-4 interacted with allosteric residue Thr 232 and the flap region. The additional $\pi-\pi$ interactions between 2, 3, and 5 with Tyr71 promoted ligand-enzyme binding. In addition, MLT, 1, 3, and 5 significantly protected neuron cells from oxidative stress by increasing the cell viability to 97.95 , $74.29,70.80$, and $69.50 \%$ at $1 \mathrm{nM}$, respectively. Moreover, these derivatives significantly induced neurite outgrowth by increasing the neurite length and number. The derivatives 1,3 , and 5 should be thoroughly studied as potential AD treatment and neuroprotective agents.
\end{abstract}

Keywords: melatonin; Alzheimer's disease; P19-derived neuron; neurite outgrowth; neuroprotection; molecular docking

\section{Introduction}

Alzheimer's disease (AD) is the most common form of dementia, and the symptoms include loss of memory, difficulty dealing with problems, and disorientation regarding time and place [1]. Although the etiology of $\mathrm{AD}$ is unknown, several pathological hallmarks, such as oxidative stress, amyloid- $\beta(A \beta)$ deposition, tau protein accumulation, and decreased levels of acetylcholine (ACh), show significant roles in the pathophysiology of this disease [2]. Many hypotheses have been developed to explain the occurrence of these hallmarks. The cholinergic hypothesis was the first theory proposed to explain AD. A decrease in cholinergic activity is usually observed in the brains of AD patients. Previous studies in both humans and primates have proposed a function of ACh in learning and memory [3,4]. This hypothesis has led to clinical studies uses a type of cholinergic agonist, acetylcholinesterase inhibitors (AChEIs), which exhibited promise in reversing memory loss in AD patients. Currently, the US Food and Drug Administration (USFDA) has approved treatments 
to treat the manifestations of AD including four AChEI drugs: rivastigmine, galantamine, donepezil, and a NMDA receptor antagonist called memantine. However, these treatment strategies only delay the progression of symptoms associated with AD [5]. Turning to the amyloid cascade hypothesis, $\mathrm{A} \beta$ is derived from proteolytic processing of the amyloid precursor protein (APP) by the sequential cleavage of beta-site APP cleaving enzyme-1 (BACE1, $\beta$-secretase) and $\gamma$-secretase [6]. Consequently, $\mathrm{A} \beta$ peptides inherently aggregate into soluble oligomers, form fibrils, and are lastly deposited as senile plaques [7]. It has been reported that $A \beta$ with 42 amino acid (A $\beta 42)$ oligomers induce oxidative damage, promote tau hyperphosphorylation, and result in toxicity in synapses and mitochondria $[2,8]$. $A \beta$ oligomers aggregates are also considered responsible for neuronal and vascular degeneration in $\mathrm{AD}$ brains [9]. The inhibition of BACE1 is an attractive approach for blocking the formation of $\mathrm{A} \beta$, because this enzyme plays a key role in the rate-limiting step of $A \beta$ production [10].

Melatonin (N-acetyl-5-methoxytryptamine; MLT) is known as a powerful antioxidant and free radical scavenger [11]. For neuroprotection and pharmacological activity against AD, MLT showed preventive effects on the death of cerebellar granule cell cultures exposed to kainate, a neuronal toxin [12]. Neuroblastoma cells incubated with A $\beta$ presented several features of apoptosis-e.g., cellular shrinkage and membrane bleb formation-and exerted anti-amyloid actions through several mechanisms. The addition of MLT to the cultures significantly reduced these features [13]. Moreover, MLT decreased the level of $A \beta$ in murine neuroblastoma transfected with amyloid precursor protein (N2aAPP) and restored the levels of phosphorylated and non-phosphorylated neurofilaments [14,15]. Earlier administrations of MLT reduced the $A \beta$ and abnormal nitration protein levels and increased survival in AD transgenic mice Tg2576 [16]. Aged mice typically present significant memory and learning impairments and increased expression levels of BACE1 and $\gamma$-secretase in their hippocampus. MLT treatment downregulated these proteins levels and restored the impaired memory [17]. In addition, long-term treatment with $6 \mathrm{mg} /$ day of MLT improved sleep quality and suppressed sundowning; this was an effect seen regardless of the concomitant medication employed to treat the cognitive or behavioral signs of AD in 45 patients with sleep disturbances [18]. However, MLT presented limitations in pharmacokinetics, such as a low oral bioavailability and short half-life [19]. Many attempts have been designed and MLT hybrid ligands have been synthesized. The combination of MLT and neurological relevant agents based on a multitarget-directed approach has been designed to enhance the activity against neurodegenerative disorders - for example, tacrine, curcumin, berberine, donepezil, etc. [20]. However, these interesting strategies have been investigated in pre-clinical studies. In our continuous work on neuroprotective effect of MLT, MLT and 5-methoxytryptamine (5-MT) derivatives with lipophilic substituents (1-5) (Figure 1) were designed and screened for antioxidant activities. Interestingly, all the derivatives showed stronger antioxidant activity than the parent MLT and 5-MT, and one exhibited a neuroprotective effect on P19-derived neurons [21,22]. As mentioned earlier, potential therapeutic treatments for AD should act on targeted enzymes, attenuate oxidative stress, and preserve the neuronal integrity or block the progression of the disease in various molecular pathways. Therefore, this study aims to investigate the inhibitory effects against AD-targeted enzymes, such as AChE and BACE1, and the neuroprotective and neuritogenic activities of these new MLT derivatives 1-5. 


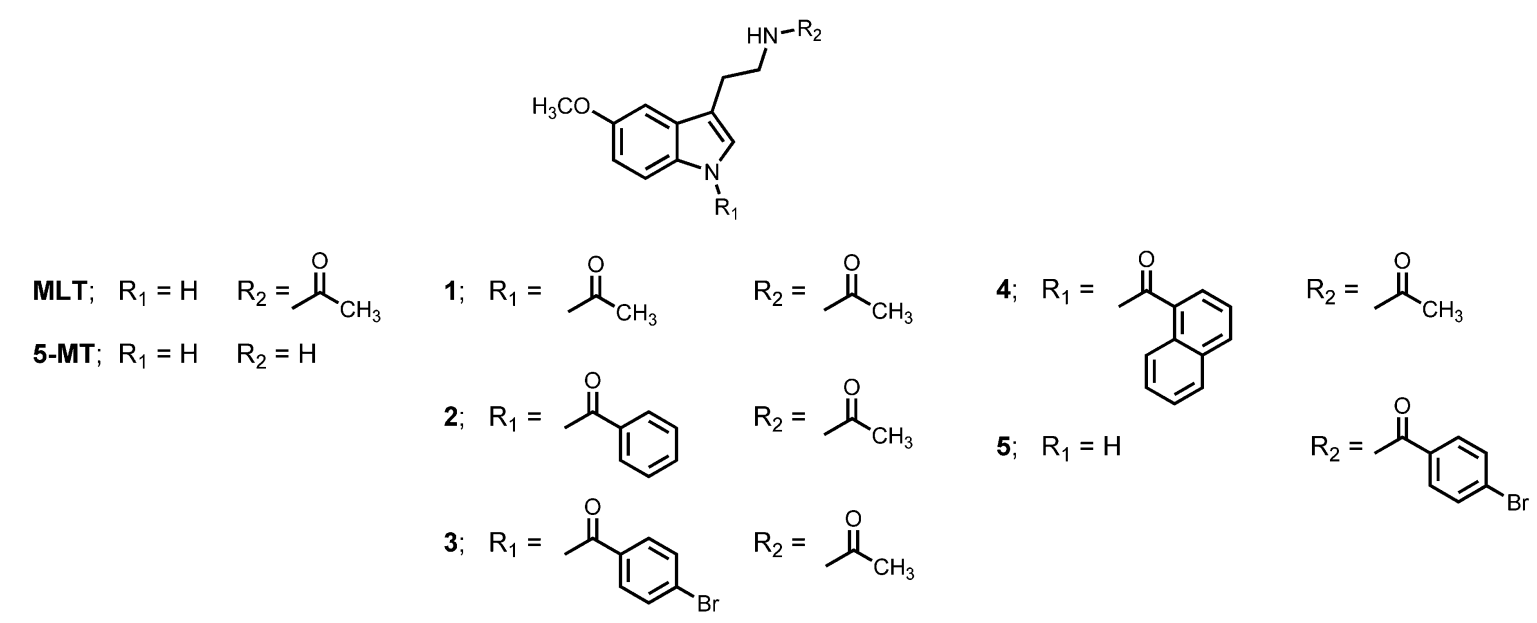

Figure 1. Chemical structure of melatonin (MLT), 5-methoxytryptamine (5-MT), and derivatives 1-5.

\section{Materials and Methods}

\subsection{In Vitro Inhibition Study on $\beta$-Secretase (BACE1) Enzyme}

Enzyme inhibitory investigations were carried out using a BACE1 fluorescence resonance energy transfer assay. Briefly, $10 \mu \mathrm{L}$ of BACE1 (Thermo Fisher Scientific Inc., Waltham, MA, USA) enzyme solution (1.0 unit/mL), $10 \mu \mathrm{L}$ of the tested compound, and $10 \mu \mathrm{L}$ of $750 \mathrm{nM} \beta$-secretase substrate IV (Calbiochem ${ }^{\circledR}$, Merck, Darmstadt, Germany) were added to the reaction wells. The reactions were incubated for $60 \mathrm{~min}$ at room temperature. The fluorescence was measured at $380 \mathrm{~nm}$ (excitation) and $510 \mathrm{~nm}$ (emission) using the SpectraMax Gemini EM ${ }^{\mathrm{TM}}$ (Molecular Devices, San Jose, CA, USA) [23]. The assay was performed for 3 independent experiments, and each of them was run in triplicate.

\subsection{In Vitro Inhibition Study on Acetylcholinesterase (AChE) Enzyme}

The measurement of the AChE inhibitory effect was modified from the spectrophotometric assays described by Ellman [24] and Petrachaianan [25]. Shortly, $125 \mu \mathrm{L}$ of $3 \mathrm{mM}$ 5,5'-dithiobis-(2-nitrobenzoic acid) (DTNB), $25 \mu \mathrm{L}$ of $1.5 \mathrm{mM}$ acetylthiocholine iodide (ATCI), and $25 \mu \mathrm{L}$ of sample were dissolved in $50 \mu \mathrm{L}$ of $50 \mathrm{mM}$ TRIS-HCl buffer $\mathrm{pH} 8.0$ and added to the wells. Then, $25 \mu \mathrm{L}$ of $0.28 \mathrm{U} / \mathrm{mL}$ AChE from Electrophorus electricus (Sigma-Aldrich, St. Louis, MO, USA) was added. The absorbance was measured at $405 \mathrm{~nm}$ by a microplate reader (Bio-Tek Instrument, Winooski, VT, USA). Three independent experiments were performed and each experiment was run in triplicate.

\subsection{Molecular Modelling}

To further elucidate the binding modes of the tested compounds with human BACE1, molecular modelling was utilized. The crystal structure of human BACE1 was obtained from the Protein Data Bank (PDB code: 2IRZ). Heteroatoms and water molecules were removed using WebLab ViewerPro (Accelrys Inc., San Diego, CA, USA), and hydrogen atoms were added by AutoDockTools version 1.5.2 [26]. Docking calculations were carried out using AutoDock 4.2 and AutoGrid 4.2 (Scripps Research, La Jolla, CA, USA) with grid dimensions of $60 \times 60 \times 60$ with a $0.375 \AA$ A grid spacing [27]. Docking validation with root-mean square deviation $($ RMSD) $=0.362 \AA$ was performed with the empirical free energy function, employing the Lamarckian genetic algorithm with local search [28]. Two hundred genetic algorithm (GA) runs were generated, with 2,500,000 energy evaluations each run.

\subsection{Neuroprotective Assay}

P19-derived neurons were differentiated by the treatment of murine P19 embryonic carcinoma cells (ATCC CRL-1825, ATCC, Manassas, VA, USA) with $0.5 \mu \mathrm{M}$ of trans-retinoic acid (RA) for 14 days $[29,30]$. Neuroprotective assay in serum-deprived conditions was carried out on P19-derived neurons cultured 
in a 96-well plate and performed in triplicate. The medium was removed and the DMSO solution of the tested compounds was diluted with $10 \mu \mathrm{M}$ of Ara-C, and $\alpha$-MEM supplemented with $10 \mu \mathrm{M}$ of Ara-C and 1\% antibiotics-antimycotic solution without fetal bovine serum (FBS) was added to give a final concentration of the compounds that enhanced the survival of cultured neurons more than the control. DMSO was added to the cultures at $0.5 \%$ as a control. To generate oxidative stress conditions, the neuron cultures were incubated in medium without FBS in a $5 \% \mathrm{CO}_{2}$ humidified atmosphere at $37^{\circ} \mathrm{C}$ for $18 \mathrm{~h}$ [31-33]. Quercetin (positive control) and all the tested compounds were added into the wells at a concentration of $1 \mathrm{nM}$. The cell viability was measured by the XTT reduction method. Three independent experiments were performed and each experiment was run in triplicate. The data were expressed as the mean $\pm \mathrm{SD}$.

\subsection{Neuritogenic Assay}

P19-derived neurons were cultured in a 6-well plate. Quercetin (positive control) and all the tested compounds were added into the wells at a concentration of $1 \mathrm{nM}$. Neuron appearance and morphology were observed and compared with the control and measured for the length and number of neurite under a phase-contrast microscope. Thirty neurons from the assay were measured for the average length and number of neurites. The data were expressed as the mean \pm SD.

\subsection{Statistical Analysis}

All the results were analyzed using Statistical Product and Service Solution software (SPSS) version 19.0 (SPSS Inc., Chicago, IL, USA) and showed as the mean \pm standard deviation (SD). Statistical analysis analyzed by one-way analysis of variance, and the significance was set as a $p$-value of less than 0.05 .

\section{Results}

\subsection{Inhibitory Effect on BACE1 and AChE}

The evaluation of the effects on BACE1 activity revealed that MLT, 5-MT, and all derivatives (1-5) significantly inhibited BACE1 activity more than quercetin (positive control) at the same concentration $(5 \mu \mathrm{M})$. All the derivatives had inhibitory activities more than $75 \%$, and compound 1 was the most effective in this assay (Table 1). Meanwhile, all the derivatives, including their parent compounds, MLT and 5-MT, presented extremely low inhibitory effects on AChE, less than $10 \%$ at $100 \mu \mathrm{M}$. Therefore, the binding modes of all the compounds on BACE1 were further studied.

Table 1. Inhibitory effects of MLT and derivatives 1-5 on $\beta$-secretase (BACE1) and acetylcholinesterase (AChE).

\begin{tabular}{|c|c|c|}
\hline \multirow{2}{*}{ Compounds } & \multicolumn{2}{|c|}{ \%Inhibition } \\
\hline & $\mathrm{AChE} \pm \mathrm{SD}$ at $100 \mu \mathrm{M}$ & $\mathrm{BACE} 1 \pm \mathrm{SD}$ at $5 \mu \mathrm{M}$ \\
\hline MLT & $4.82 \pm 3.13$ & $83.23 \pm 1.93 *$ \\
\hline 5-MT & $4.44 \pm 3.73$ & $66.94 \pm 2.31^{* * * *}$ \\
\hline 1 & $6.57 \pm 3.04$ & $87.74 \pm 1.14$ * \\
\hline 2 & $5.76 \pm 3.45$ & $84.70 \pm 3.79 *$ \\
\hline 3 & $5.31 \pm 2.37$ & $79.56 \pm 3.42 *$ \\
\hline 4 & $6.84 \pm 4.75$ & $76.53 \pm 3.40 *$ \\
\hline 5 & $6.43 \pm 2.67$ & $86.92 \pm 1.60 *$ \\
\hline Quercetin & $\mathrm{ND}^{\mathrm{a}}$ & $48.46 \pm 1.02$ \\
\hline Galantamine $(35 \mu \mathrm{M})$ & $97.24 \pm 0.54$ & $\mathrm{ND}^{\mathrm{a}}$ \\
\hline
\end{tabular}




\subsection{Molecular Interactions with BACE1 by Molecular Docking}

To obtain more understanding of the molecular interactions of all compounds to the target BACE1, molecular docking was further performed. BACE1 is a membrane-bound aspartyl protease with the important catalytic site residues, such as Asp32 and Asp 228. These Asp residues are covered with 11 amino acid residues (Val67-Glu77) - i.e., the fragment antiparallel hairpin loop known as "flap" [34]. The cleavage of APP is catalyzed by BACE1 at the Asp dyad residues; the flap region facilitates the entry of the ligands into the active site $[34,35]$. Consequently, the catalytic aspartate residues (Asp32 and Asp22) and the flap region are suggested to be crucial binders for potential BACE1 inhibitors. Not only catalytic residues and flap region but the allosteric sites, including Gly34, Gln73, Tyr198, Gly230, and Thr232, also interact with the peptides or the ligands by forming hydrogen bonds. In addition, hydrophobic interactions are also formed with other residues-e.g., Tyr71, Gln73, Phe108, and Ile110 [36]. The binding affinity for all compounds with BACE1 showed binding energy values between -8.48 and $-6.72 \mathrm{kCal} / \mathrm{mol}$ and quercetin is $-6.63 \mathrm{kCal} / \mathrm{mol}$ (Table 2). These results revealed that the complexed compound-BACE1 for 1-5 was more stable than quercetin-BACE1. The binding interaction modes with BACE1 are shown in Table 2 and Figure 2. MLT, 5-MT and 5 were observed to form hydrogen bonds with the Asp32 residue and the other residues in the flap region (Tyr71 and Gln73). Moreover, the indole ring of 5 was involved in the $\pi-\pi$ interaction with the Tyr71 residue. Compound 1 only interacted with the allosteric residue Thr232 (Figure 2C), resulting in a slightly different binding energy compared with the parent compound, MLT. Compound 2 did not establish any hydrogen bonds; however, the additional aromatic ring interacted with the Tyr71 residue by hydrophobic interactions which stabilized the ligand binding (Figure 2D). Similar to compound 2, the halogenated aromatic derivative 3 also established $\pi-\pi$ interactions with the Tyr71 residue and a hydrogen bond with the Thr232 residue (Figure 2E). Although compound 4 also had an aromatic substituent, it did not establish $\pi-\pi$ interactions. This lipophilic derivative established three hydrogen bonds with the flap region stabilized by hydrophobic interactions with the allosteric residues (Figure 2F).

Table 2. Molecular interactions of the BACE1 active site with MLT and derivatives 1-5.

\begin{tabular}{|c|c|c|c|c|}
\hline \multirow{2}{*}{ Compounds } & \multirow{2}{*}{$\Delta \mathrm{G}(\mathrm{kCal} / \mathrm{mol})$} & \multicolumn{3}{|c|}{ Binding Amino Acids } \\
\hline & & H-Bond & $\pi-\pi$ & van der Waals \\
\hline MLT & -6.81 & $\begin{array}{l}\text { Asp32, Gln73, } \\
\text { Phe108, Thr232 }\end{array}$ & - & $\begin{array}{l}\text { Gln73, Phe108, } \\
\text { Ile110 }\end{array}$ \\
\hline 5-MT & -9.97 & Asp32, Asp228 & - & Gln73, Gly230 \\
\hline 1 & -6.72 & Thr232 & - & Gln73, Ile110 \\
\hline 2 & -7.88 & - & Tyr71 & $\begin{array}{l}\text { Tyr71, Gln73, } \\
\text { Phe108, Ile110 }\end{array}$ \\
\hline 3 & -8.48 & Thr232 & Tyr71 & $\begin{array}{l}\text { Tyr71, Gln73, } \\
\text { Phe108, Ile110 }\end{array}$ \\
\hline 4 & -7.93 & $\begin{array}{c}\text { Gln12, Gln73, } \\
\text { Thr232 }\end{array}$ & - & Gln73, Ile110 \\
\hline 5 & -7.66 & Asp32, Tyr71 & Tyr71 & Tyr71, Gln73, Ile110 \\
\hline Quercetin & -6.63 & $\begin{array}{l}\text { His45, Gln73, } \\
\text { Ser105, Phe108 }\end{array}$ & - & Lys107, Ile110 \\
\hline
\end{tabular}



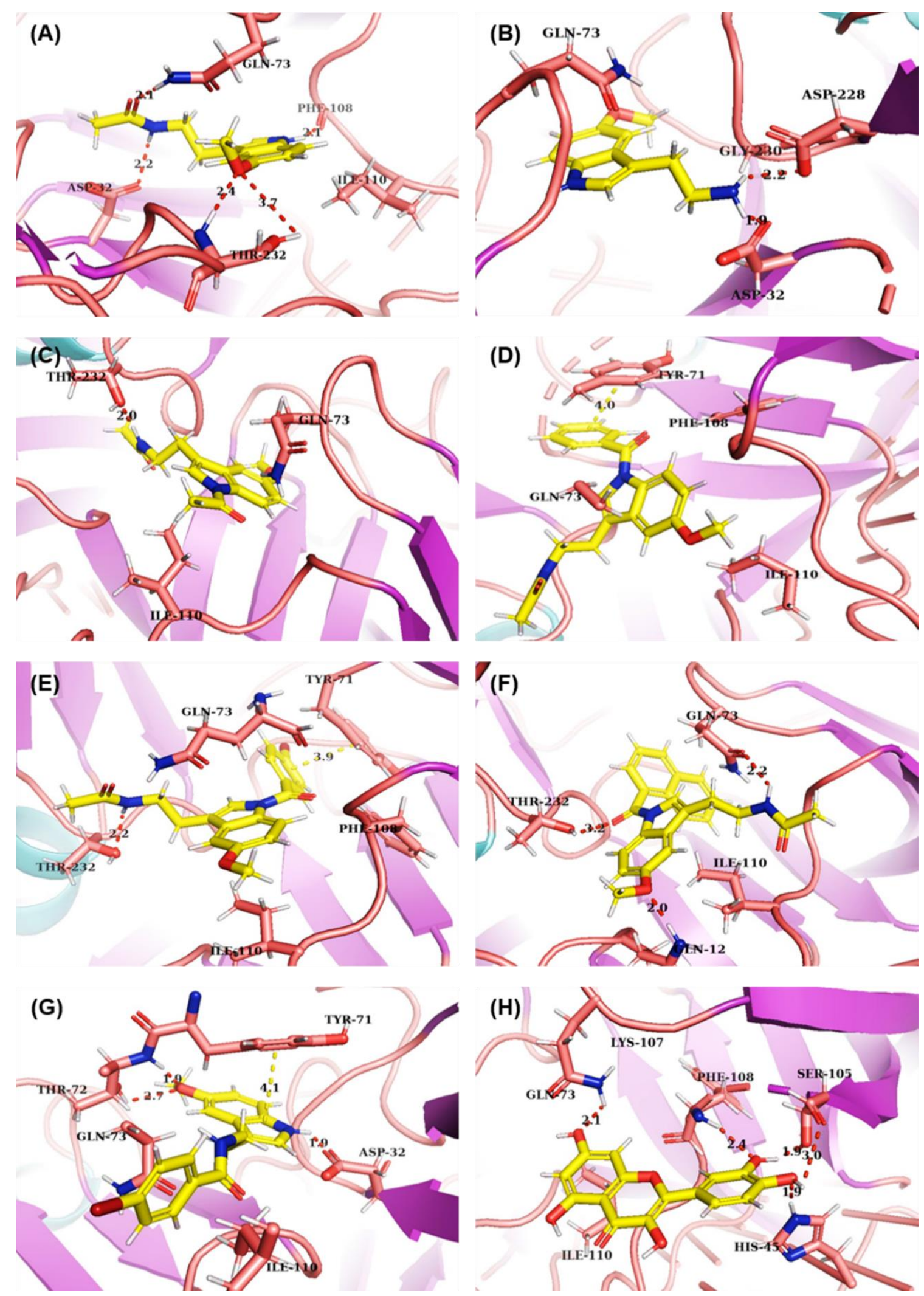

Figure 2. In silico molecular docking poses for (A) MLT, (B) 5-MT, (C) 1, (D) 2, (E) 3, (F) 4, (G) 5, and $(\mathbf{H})$ quercetin with BACE1. The red dot line represents $\mathrm{H}$-bond and the yellow dot line represents $\pi-\pi$ interactions. 


\subsection{Neuroprotective and Neuritogenic Activities}

To evaluate the effect of the compounds on the cell viability, the same concentration at $1 \mathrm{nM}$ of all compounds was used to determine the cytotoxicity in P19-derived neuron cells by the XTT reduction assay. The results indicated that MLT, 5-MT, 1, 3, and 5 could promote cell viability by more than 100\% compared with the control (0.5\% DMSO with FBS). However, compounds 2 and 4 exhibited neurotoxicity, having cell viability values of $73.58 \%$ and $56.34 \%$, respectively, compared with the control. Therefore, MLT, 5-MT, 1, 3, and 5 were further studied for neuroprotective activity. The neuroprotective assays of MLT and derivatives in oxidative stress condition are shown in Figure 3. The oxidative stress control group (0.5\% DMSO without FBS) dramatically reduced cell viability from 98.55 to $55.09 \%$. The cells were incubated with MLT, 1, 3, and 5 significantly protected neuron cells from oxidative stress, as indicated by the $97.95,74.29,70.80$, and $69.50 \%$ increased on cell viability. 5-MT also increased cell viability $(62.84 \%)$ but not by any significant amount.

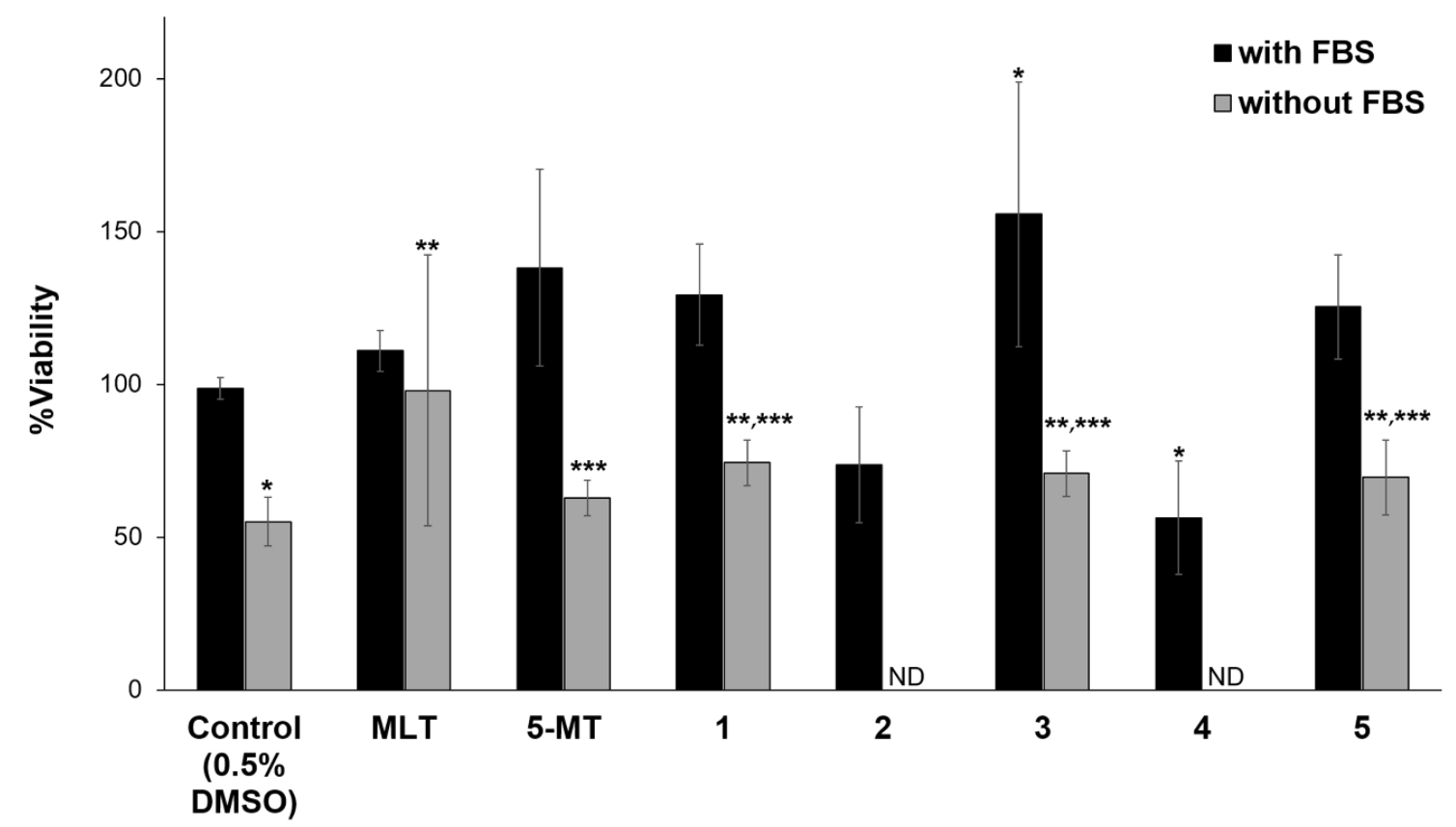

Figure 3. Effects of MLT and derivatives 1-5 on the cell viabilities of P19-derived neurons cultured in conditions with fetal bovine serum (FBS) (black bar) and without FBS (grey bar). ${ }^{*} p<0.05$ compared with control with FBS, ${ }^{* *} p<0.05$ compared with control without FBS, and ${ }^{* * *} p<0.05$ compared with MLT without FBS. ND is not determined.

The neuritogenic activity was also determined at $1 \mathrm{nM}$. After treatment with the compounds, the morphology, length, and number of neurites were observed under phase-contrast microscope (Figure 4). All the tested compounds significantly increased the number of neurites growth over the control group. Bromo-benzoylated derivatives 3 and 5 presented the highest effects on increased neurite branching. Compounds 1, 3, and 5 significantly increased the lengths of the neurites (Table 3). 

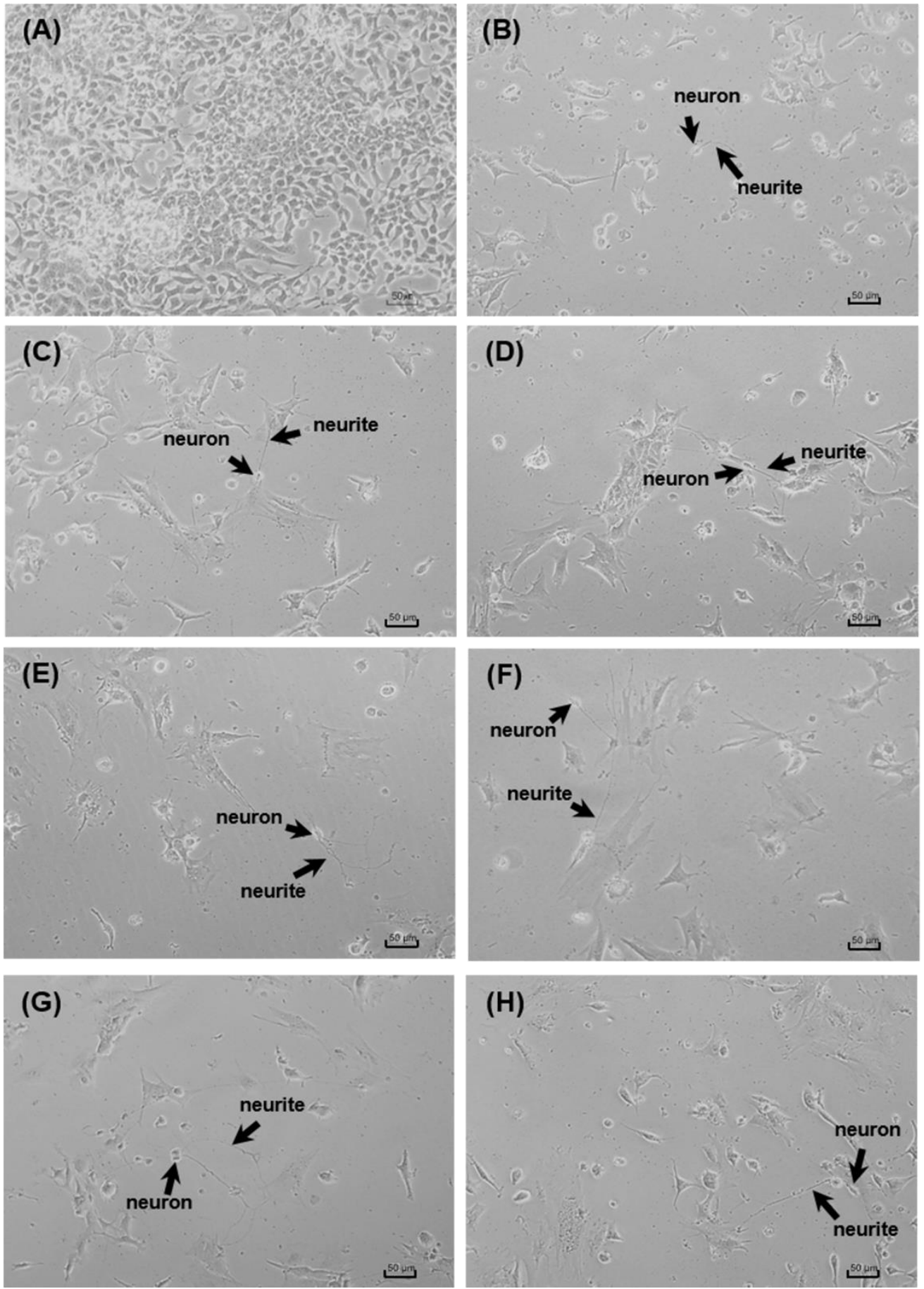

Figure 4. Phase-contrast micrographs of (A) undifferentiated P19 cells and P19-derived neurons after treatment with $1 \mathrm{nM}$ (B) 0.5\% DMSO, (C) MLT, (D) 5-MT, (E) 1, (F) 3, (G) 5, and (H) quercetin. The arrow indicates neuron and neurite of P19-derived neurons in each group. 
Table 3. Neuritogenic effects of MLT and derivatives 1-5 on P19-derived neuron cells.

\begin{tabular}{|c|c|c|c|c|}
\hline \multirow{2}{*}{ Compounds } & \multicolumn{2}{|c|}{ Number of Neurites } & \multicolumn{2}{|c|}{ Neurite Length } \\
\hline & Average \pm SD & $\%$ Increase & Average \pm SD & \%Increase \\
\hline $\begin{array}{l}\text { Control }(0.5 \% \\
\text { DMSO) }\end{array}$ & $1.50 \pm 0.51$ & 0.00 & $70.42 \pm 54.40$ & 0.00 \\
\hline Quercetin & $2.80 \pm 1.00$ & 86.67 & $85.34 \pm 53.31$ & 21.19 \\
\hline MLT & $2.90 \pm 0.71 *$ & 93.33 & $63.94 \pm 31.91$ & -9.20 \\
\hline 5-MT & $3.63 \pm 1.22 *, * *, * * *$ & 142.00 & $69.23 \pm 40.83$ & -1.69 \\
\hline 1 & $3.20 \pm 1.16^{*}$ & 113.33 & $97.96 \pm 65.67 * * *$ & 39.11 \\
\hline 3 & $4.60 \pm 1.57^{*, * * * * * *}$ & 206.67 & $95.00 \pm 70.35 * * *$ & 34.90 \\
\hline 5 & $3.73 \pm 1.14^{*, * * * * * *}$ & 148.67 & $102.87 \pm 78.83^{*, * * *}$ & 46.08 \\
\hline
\end{tabular}

\section{Discussion}

The derivatives of MLT (1-5) were evaluated by comparing their activities against AD with those of the parent compound. Similar to their parent compound, none of the derivatives presented an inhibitory effect on AChE activity. Previous studies have reported that the long-term treatment of MLT in APP 695 transgenic mice significantly prevented decreases in choline acetyltransferase (ChAT) activity but did not alter the AChE activity in the frontal cortex or hippocampus [37]. Therefore, the other targeted enzyme, BACE1, against $\mathrm{AD}$ was further investigated in this study.

BACE1 is an attractive target for therapeutic agents against AD. The earlier generation of BACE1 inhibitors which are peptidomimetic molecules encountered pharmacokinetic problems such as absorption, half-life, and blood-brain barrier (BBB) penetration [38]. Although the small molecules inhibitors had improved pharmacokinetic properties, most of them were the substrates of P-glycoprotein, resulting in the drugs not reaching therapeutic concentration at the target site [39]. Having the appropriate partition coefficient $(\log \mathrm{P})$, not being the efflux pump substrate and distributing widely to BBB, the pineal hormone, MLT, is an interesting molecule for the development of BACE1 inhibitor. [19]. Moreover, the derivatives 1-5 were predicted their physicochemical properties by the SwissADME program [40]. Their $\log P$ values were in the range of 1.99 to 4.17 and were not substrates of P-glycoprotein, indicating these derivatives would permeate the membrane and cross the BBB. Therefore, we focused on the inhibitory effects of MLT and its derivatives on the BACE1 activity. The results from the BACE1 fluorescence assay in Table 1 presented that all the compounds had a significantly higher BACE1 inhibitory activity $(67-88 \%)$ than that of quercetin (48\%) at the same concentration $(5 \mu \mathrm{M})$. The results also showed that the modifications 1-5, including their parents MLT and 5-MT, can be considered to have a potent inhibitory effect against BACE1 [23,41]. Our in silico molecular docking study revealed the interactions and binding energy of quercetin. Quercetin, a well-known BACE1 inhibitor, was predicted to have no interaction with the catalytic residues. It established hydrogen bonds with flap region residue (Gln73) and allosteric residues resulting in higher binding energy than all the tested compounds. According to the in vitro experiment, quercetin presented a lower inhibitory effect on BACE1 than MLT and its derivatives, which is in accordance with the in silico prediction. The un-substituted at N1-indole core structures including MLT, 5-MT, and 5 could interact with the catalytic residue Asp32 and the flap region residue by hydrogen bonds. The addition of N1-substituted groups (1-4) changed the orientation of the structure and affected the binding mode with the enzyme. These compounds interacted with the allosteric residue (Thr232) instead of the catalytic site, and the additional aromatic rings of 2, 3, and 5 played important roles for $\pi-\pi$ interactions. Recently, the investigation of the BACE1 inhibitory modes found that the inhibition at the catalytic site would relate to mechanism-based side effects in mice. Allosteric inhibition would be alternative target site for the design of BACE1 inhibitors [38,42,43]

MLT and the derivatives were also investigated for their neuroprotective and neuritogenic effects on the cell viability of P19-derived neurons. The P19 cell line is a suitable cell line for AD testing 
because it can differentiate into neurons after treatment with RA for 4-5 days. These neurons are irreversibly postmitotic and present the antigen in the nucleus of neurons of the central nervous system [30]. At a cell density of $10^{4}$ cells $/ \mathrm{cm}^{2}$, these cells differentiate into cholinergic neurons, where the neurotransmitter ACh was found [44]. From phase-contrast microscope, the morphology of RA-treated cells changed from a polygonal shape to round cell bodies with a long branching process (Figure 4). From our previous study, MLT was evaluated the cytotoxicity on P19-derived neurons at a concentration 1-10,000 nM and it was found that the trend of toxicity was concentration-dependent [21]. Therefore, the lowest non-cytotoxic concentration at $1 \mathrm{nM}$ was selected for neuroprotective and neuritogenic studies. FBS was withdrawn from neuron cells, then the oxidative stress was generated $[31,45]$. This condition caused a cell death of almost 50\% in the control group. MLT, 1, 3, and 5 significantly increased the neuronal viability in the oxidative stress condition compared with the control group (Figure 3). From a previous study, MLT, 3, and 5 exhibited good antioxidant capacities, as shown in the ORAC assay [22]. Our results indicated the neuroprotective effect of MLT and its derivative effect by the antioxidant. For a neuritogenic study, all the tested compounds significantly increased in neurite number by 113-206\% compared with the control (Table 3). Moreover, the bromobenzoly-modified compounds 3 and 5 has a significantly greater number of neuron cells than the parent compounds, MLT and 5-MT, and standard quercetin. Interestingly, derivatives 1, 3, and 5 had significantly longer neurite lengths than quercetin. The neuron cells incubated with $\mathbf{1}, \mathbf{3}$, and 5 increased the neurite length up to $34-46 \%$ compared with the control. This corresponded to the study of Lui et al. [46], which showed that MLT was able to enhance the proliferation and neurite outgrowth of PC12 cells. From previous results, the increasing of the number and length of neuron cells was related to the BACE1 inhibitory activity. This result might be the effect of ratio of soluble amyloid precursor protein alpha $(\mathrm{sAPP} \alpha)$. The increasing sAPP $\alpha$ could bind to $\mathrm{p} 75$ neurotrophin receptor $\left(\mathrm{p} 75^{\mathrm{NTR}}\right)$ and stimulate neurite outgrowth with a lower stress on neuron cells $[47,48]$. Therefore, other proposed neurite outgrowth mechanisms of derivatives 1, 3, and 5 will be performed in a further study.

Our MLT derivatives were developed to overcome the pharmacokinetic limitation of MLT by the substitution of more lipophilic groups. The derivatives were proposed to have a longer half-life than MLT, but still present pharmacological activities, especially antioxidant and neuroprotective activities, similar to their parent compound. From all experiments, the derivatives 1, 3, and 5 showed outstanding abilities comparable to those of MLT and had potential as lead compounds for neuroprotective agents. In addition, other mechanisms against $\mathrm{AD}$, such as ChAT activity, $\mathrm{A} \beta$ aggregation, and tau protein accumulation, should be investigated and the toxicities of these molecules should be tested both in vivo and in vitro.

\section{Conclusions}

MLT, 5-MT, and all derivatives 1-5 showed potent inhibitory effects on BACE1 at $5 \mu \mathrm{M}$ compared with the positive inhibitor, quercetin. In silico molecular modelling predicted that MLT, 5-MT, and 5 interact with BACE1 at the catalytic site and the flap region, whereas 1-4 interacted with allosteric residue Thr232 and the flap region. The additional $\pi-\pi$ interactions between the benzene ring of 2,3 , and 5 with the Tyr71 residue promoted ligand-enzyme binding. MLT, 1, 3, and 5 significantly protected cell death in oxidative stress conditions. Furthermore, these derivatives exhibited neuritogenic effects on the neurite number and length. From our study, the derivatives 1, 3, and 5 presented the prominent BACE1 inhibitory activity, exhibited neuroprotective ability against oxidative stress, and promoted neurite outgrowth, which brought new insights into the future of new MLT derivatives as candidates for therapeutics against $\mathrm{AD}$ and neuroprotective agents.

Author Contributions: Conceptualization, P.P. (Ploenthip Puthongking); methodology, P.P. (Ploenthip Puthongking), S.T., and P.P. (Panyada Panyatip); formal analysis, P.P. (Ploenthip Puthongking), S.T., P.P. (Panyada Panyatip), and E.S.; investigation, P.P. (Ploenthip Puthongking), S.T., P.P. (Panyada Panyatip), and E.S.; resources, P.P. (Ploenthip Puthongking), S.T. and P.P. (Panyada Panyatip); writing—original draft preparation, P.P. (Ploenthip Puthongking), S.T. and P.P. (Panyada Panyatip); writing-review and editing, P.P. (Ploenthip Puthongking), S.T., E.S., and P.P. (Panyada Panyatip); visualization, P.P. (Ploenthip Puthongking); supervision, P.P. (Ploenthip 
Puthongking) and S.T.; project administration, P.P. (Ploenthip Puthongking); funding acquisition, P.P. (Ploenthip Puthongking). P.P. (Panyada Panyatip) and S.T. contributed equally to the work. All authors have read and agreed to the published version of the manuscript.

Funding: This research was supported by Research and Academic Services, Khon Kaen University (RP63002) and The Office of the Higher Education Commission (Total Synthesis of Melatonin Project) Thailand. This research was also supported by national funds through FCT-Foundation for Science and Technology within the scope of UIDB/04423/2020 and UIDP/04423/2020.

Acknowledgments: Panyada Panyatip would like to thank The National Research Council of Thailand (NRCT) to provide research fund under the Graduate Research Fund Academic Year 2019.

Conflicts of Interest: Authors declare that have no conflict of interest.

\section{References}

1. Sanabria-Castro, A.; Alvarado-Echeverria, I.; Monge-Bonilla, C. Molecular Pathogenesis of Alzheimer's Disease: An Update. Ann. Neurosci. 2017, 24, 46-54. [CrossRef] [PubMed]

2. Kurz, A.; Perneczky, R. Amyloid Clearance as a Treatment Target against Alzheimer's Disease. J. Alzheimer's Dis. 2011, 24, 61-73. [CrossRef] [PubMed]

3. Davies, P.; Maloney, A.J.F. Selective Loss of Central Cholinergic Neurons in Alzheimer's Disease. Lancet 1976, 308, 1403. [CrossRef]

4. Perry, E.K.; Tomlinson, B.E.; Blessed, G.; Perry, R.H.; Cross, A.J.; Crow, T.J. Neuropathological and Biochemical Observations on the Noradrenergic System in Alzheimer's Disease. J. Neurol. Sci. 1981, 51, 279-287. [CrossRef]

5. Kumar, A.; Dogra, S. Neuropathology and Therapeutic Management of Alzheimer's Disease-An Update. Drugs Future 2008, 33, 433-446. [CrossRef]

6. Salomone, S.; Caraci, F.; Leggio, G.M.; Fedotova, J.; Drago, F. New Pharmacological Strategies for Treatment of Alzheimer's Disease: Focus on Disease Modifying Drugs. Br. J. Clin. Pharmacol. 2012, 73, 504-517. [CrossRef]

7. Hardy, J. The Amyloid Hypothesis for Alzheimer's Disease: A Critical Reappraisal. J. Neurochem. 2009, 110, 1129-1134. [CrossRef]

8. Kumar, A.; Singh, A. A Review on Alzheimer's Disease Pathophysiology and Its Management: An Update. Pharmacol. Rep. 2015, 67, 195-203. [CrossRef]

9. Roth, A.D.; Ramirez, G.; Alarcon, R.; Von Bernhardi, R. Oligodendrocytes Damage in Alzheimer's Disease: Beta Amyloid Toxicity and Inflammation. Biol. Res. 2005, 38, 381-387. [CrossRef]

10. Zeng, H.; Wu, X. Alzheimer's Disease Drug Development Based on Computer-Aided Drug Design. Eur. J. Med. Chem. 2016, 121, 851-863. [CrossRef]

11. Cardinali, D.P. Melatonin: Clinical Perspectives in Neurodegeneration. Front. Endocrinol. 2019, 10, 480. [CrossRef] [PubMed]

12. Mor, M.; Silva, C.; Vacondio, F.; Plazzi, P.V.; Bertoni, S.; Spadoni, G.; Franceschini, D. Indole-Based Analogs of Melatonin: In Vitro Antioxidant and Cytoprotective Activities. J. Pineal Res. 2004, 36, 95-102. [CrossRef] [PubMed]

13. Pappolla, M.A.; Sos, M.; Omar, R.A.; Bick, R.J.; Hickson-Bick, D.L.; Reiter, R.J.; Robakis, N.K. Melatonin Prevents Death of Neuroblastoma Cells Exposed to the Alzheimer Amyloid Peptide. J. Neurosci. 1997, 17, 1683-1690. [CrossRef]

14. Zhang, Y.C.; Wang, Z.F.; Wang, Q.; Wang, Y.P.; Wang, J.Z. Melatonin Attenuates Beta-Amyloid-Induced Inhibition of Neurofilament Expression. Acta Pharmacol. Sin. 2004, 25, 447-451. [PubMed]

15. Wang, X.C.; Zhang, Y.C.; Chatterjie, N.; Grundke-Iqbal, I.; Iqbal, K.; Wang, J.Z. Effect of Melatonin and Melatonylvalpromide on $\beta$-Amyloid and Neurofilaments in N2a Cells. Neurochem. Res. 2008, 33, 1138-1144. [CrossRef]

16. Matsubara, E.; Bryant-Thomas, T.; Pacheco Quinto, J.; Henry, T.L.; Poeggeler, B.; Herbert, D.; Shoji, M. Melatonin Increases Survival and Inhibits Oxidative and Amyloid Pathology in a Transgenic Model of Alzheimer's Disease. J. Neurochem. 2003, 85, 1101-1108. [CrossRef]

17. Mukda, S.; Panmanee, J.; Boontem, P.; Govitrapong, P. Melatonin Administration Reverses the Alteration of Amyloid Precursor Protein-Cleaving Secretases Expression in Aged Mouse Hippocampus. Neurosci. Lett. 2016, 621, 39-46. [CrossRef] 
18. Cardinali, D.P.; Brusco, L.I.; Liberczuk, C.; Furio, A.M. The Use of Melatonin in Alzheimer's Disease. Neuroendocrinol. Lett. 2002, 23, 20-23.

19. Salehi, B.; Sharopov, F.; Fokou, P.V.T.; Kobylinska, A.; Jonge, L.D.; Tadio, K.; Iriti, M. Melatonin in Medicinal and Food Plants: Occurrence, Bioavailability, and Health Potential for Humans. Cells 2019, 8, 681. [CrossRef]

20. Ramos, E.; Egea, J.; de Los Rios, C.; Marco-Contelles, J.; Romero, A. Melatonin as a Versatile Molecule to Design Novel Multitarget Hybrids against Neurodegeneration. Future Med. Chem. 2017, 9, 765-780. [CrossRef]

21. Panyatip, P.; Puthongking, P.; Tadtong, S. Neuroprotective and Neuritogenic Activities of Melatonin and N-Acetyl Substituent Derivative. Indian J. Pharm. Sci. 2015, 11, 14-19.

22. Panyatip, P.; Johns, N.P.; Priprem, A.; Nakagawa, K.; Puthongking, P. Effect of N-Amide Substitution on Antioxidative Activities of Melatonin Derivatives. Sci. Pharm. 2020, 88, 3. [CrossRef]

23. Jiaranaikulwanitch, J.; Tadtong, S.; Govitrapong, P.; Fokin, V.V.; Vajragupta, O. Neuritogenic Activity of Bi-Functional Bis-Tryptoline Triazole. Bioorg. Med. Chem. 2017, 25, 1195-1201. [CrossRef] [PubMed]

24. Ellman, G.L.; Courtney, K.D.; Andres, V., Jr.; Featherstone, R.M. A New and Rapid Colorimetric Determination of Acetylcholinesterase Activity. Biochem. Pharmacol. 1961, 7, 88-95. [CrossRef]

25. Petrachaianan, T.; Chaiyasirisuwan, S.; Athikomkulchai, S.; Sareedenchai, V. Screening of Acetylcholinesterase Inhibitory Activity in Essential Oil from Myrtaceae. Turk. J. Pharm. Sci. 2019, 43, 63-68.

26. Sanner, M.F. Python: A Programming Language for Software Integration and Development. J. Mol. Graph. Model. 1999, 17, 57-61.

27. Gupta, S.; Parihar, D.; Shah, M.; Yadav, S. Computational Screening of Promising Beta-Secretase 1 Inhibitors through Multi-Step Molecular Docking and Molecular Dynamics Simulations-Pharmacoinformatics Approach. J. Mol. Struct. 2020, 1205, 127660. [CrossRef]

28. Mashhadi, H.R.; Shanechi, H.M.; Lucas, C. A New Genetic Algorithm with Lamarckian Individual Learning for Generation Scheduling. IEEE Trans. Power Syst. 2003, 18, 1181-1186. [CrossRef]

29. Jones-Villeneuve, E.M.; McBurney, M.W.; Rogers, K.A.; Kalnins, V.I. Retinoic Acid Induces Embryonal Carcinoma Cells to Differentiate into Neurons and Glial Cells. J. Cell Biol. 1982, 94, 253-262. [CrossRef]

30. MacPherson, P.A.; McBurney, M.W. P19 Embryonal Carcinoma Cells: A Source of Cultured Neurons Amenable to Genetic Manipulation. Methods 1995, 7, 238-252. [CrossRef]

31. Iacovitti, L.; Stull, N.D.; Johnston, K. Melatonin Rescues Dopamine Neurons from Cell Death in Tissue Culture Models of Oxidative Stress. Brain Res. 1997, 768, 317-326. [CrossRef]

32. Lopez-Maderuelo, M.D.; Fernandez-Renart, M.; Moratilla, C.; Renart, J. Opposite Effects of the Hsp90 Inhibitor Geldanamycin: Induction of Apoptosis in PC12, and Differentiation in N2A Cells. FEBS Lett. 2001, 490, 23-27. [CrossRef]

33. Tadtong, S.; Kanlayavattanakul, M.; Lourith, N. Neuritogenic and Neuroprotective Activities of Fruit Residues. Nat. Prod. Commun. 2013, 8, 1583-1586. [CrossRef] [PubMed]

34. Kumar, A.; Roy, S.; Tripathi, S.; Sharma, A. Molecular Docking Based Virtual Screening of Natural Compounds as Potential BACE1 Inhibitors: 3D QSAR Pharmacophore Mapping and Molecular Dynamics Analysis. J. Biomol. Struct. Dyn. 2016, 34, 239-249. [CrossRef]

35. Guevara, J.; Zahran, M. Ensemble Docking of Potential BACE1 Inhibitors for Alzheimer's Disease. FASEB J. 2019, 33, 642-644.

36. Xu, Y.; Li, M.J.; Greenblatt, H.; Chen, W.; Paz, A.; Dym, O.; Jiang, H. Flexibility of the Flap in the Active Site of BACE1 as Revealed by Crystal Structures and Molecular Dynamics Simulations. Acta Crystallogr. Sect. D 2012, 68, 13-25. [CrossRef]

37. Feng, Z.; Chang, Y.; Cheng, Y.; Zhang, B.L.; Qu, Z.W.; Qin, C.; Zhang, J.T. Melatonin Alleviates Behavioral Deficits Associated with Apoptosis and Cholinergic System Dysfunction in the APP 695 Transgenic Mouse Model of Alzheimer's Disease. J. Pineal Res. 2004, 37, 129-136. [CrossRef]

38. Vassar, R. BACE1 Inhibitor Drugs in Clinical Trials for Alzheimer's Disease. Alzheimer's Res. Ther. 2014, 6, 89. [CrossRef]

39. Marques, F.; Sousa, J.C.; Sousa, N.; Palha, J.A. Blood-Brain-Barriers in Aging and in Alzheimer's Disease. Mol. Neurodegener. 2013, 8, 38. [CrossRef]

40. Daina, A.; Michielin, O.; Zoete, V. SwissADME: A free Web Tool to Evaluate Pharmacokinetics, Drug-Likeness and Medicinal Chemistry Friendliness of Small Molecules. Sci. Rep. 2017, 7, 2717. [CrossRef] 
41. Zhao, X.J.; Gong, D.M.; Jiang, Y.R.; Guo, D.; Zhu, Y.; Deng, Y.C. Multipotent AChE and BACE-1 Inhibitors for the Treatment of Alzheimer's Disease: Design, Synthesis and Bio-Analysis of 7-Amino-1, 4-Dihydro-2H-Isoquilin-3-one Derivates. Eur. J. Med. Chem. 2017, 138, 738-747. [CrossRef] [PubMed]

42. Halima, S.B.; Mishra, S.; Raja, K.M.P.; Willem, M.; Baici, A.; Simons, K.; Rajendran, L. Specific Inhibition of $\beta$-Secretase Processing of the Alzheimer Disease Amyloid Precursor Protein. Cell Rep. 2016, 14, 2127-2141. [PubMed]

43. Seong, S.H.; Ali, M.Y.; Kim, H.R.; Jung, H.A.; Choi, J.S. BACE1 Inhibitory Activity and Molecular Docking Analysis of Meroterpenoids from Sargassum Serratifolium. Bioorg. Med. Chem. 2017, 25, 3964-3970. [CrossRef] [PubMed]

44. Parnas, D.; Linial, M. Cholinergic Properties of Neurons Differentiated from an Embryonal Carcinoma Cell-Line (P19). Int. J. Dev. Neurosci. 1995, 13, 767-781. [CrossRef]

45. Atabay, C.; Cagnoli, C.M.; Kharlamov, E.; Ikonomovic, M.D.; Manev, H. Removal of Serum from Primary Cultures of Cerebellar Granule Neurons Induces Oxidative Stress and DNA Fragmentation: Protection with Antioxidants and Glutamate Receptor Antagonists. J. Neurosci. Res. 1996, 43, 465-475. [CrossRef]

46. Liu, Y.; Zhang, Z.; Lv, Q.; Chen, X.; Deng, W.; Shi, K.; Pan, L. Effects and Mechanisms of Melatonin on the Proliferation and Neural Differentiation of PC12 Cells. Biochem. Biophys. Res. Commun. 2016, 478, 540-545. [CrossRef] [PubMed]

47. Mattsson, N.; Rajendran, L.; Zetterberg, H.; Gustavsson, M.; Andreasson, U.; Olsson, M.; Neumann, U. BACE1 Inhibition Induces a Specific Cerebrospinal Fluid $\beta$-Amyloid Pattern that Identifies Drug Effects in the Central Nervous System. PLoS ONE 2012, 7, e31084. [CrossRef]

48. Hasebe, N.; Fujita, Y.; Ueno, M.; Yoshimura, K.; Fujino, Y.; Yamashita, T. Soluble $\beta$-amyloid precursor protein alpha binds to p75 neurotrophin receptor to promote neurite outgrowth. PLoS ONE 2013, 8, e82321. [CrossRef]

Publisher's Note: MDPI stays neutral with regard to jurisdictional claims in published maps and institutional affiliations.

(C) 2020 by the authors. Licensee MDPI, Basel, Switzerland. This article is an open access article distributed under the terms and conditions of the Creative Commons Attribution (CC BY) license (http://creativecommons.org/licenses/by/4.0/). 